This article was downloaded by: [University of Sydney]

On: 01 September 2014, At: 14:59

Publisher: Routledge

Informa Ltd Registered in England and Wales Registered Number: 1072954 Registered office: Mortimer House, 37-41 Mortimer Street, London W1T 3J H, UK

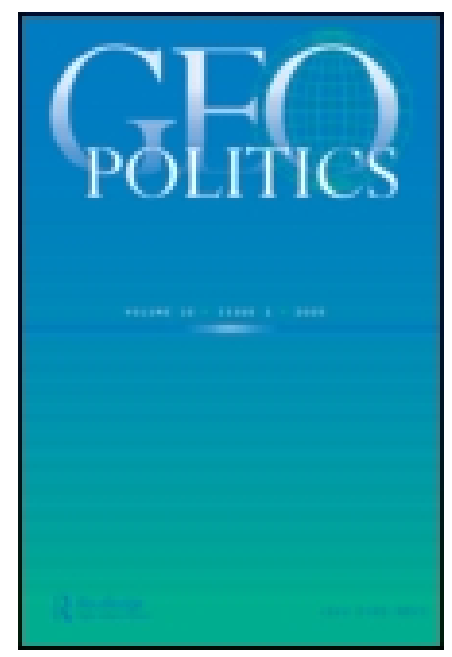

\title{
Geopolitics
}

Publication details, including instructions for authors and subscription information:

http:// www.tandfonline.com/ loi/ fgeo20

\section{The Three Critical Flaws of Critical Geopolitics: Towards a Neo-Classical Geopolitics}

Terrence W. Haverluk ${ }^{a}$, Kevin M. Beauchemin ${ }^{a}$ \& Brandon A. Mueller $^{\mathrm{a}}$

a Academy Scholars Program, United States Air Force Academy, USAFA , CO , USA

Published online: $21 \mathrm{~J}$ an 2014.

To cite this article: Terrence W. Haverluk, Kevin M. Beauchemin \& Brandon A. Mueller (2014) The Three Critical Flaws of Critical Geopolitics: Towards a Neo-Classical Geopolitics, Geopolitics, 19: 1, 19-39, DOI: 10.1080/ 14650045.2013.803192

To link to this article: http:// dx. doi.org/ 10.1080/ 14650045.2013.803192

\section{PLEASE SCROLL DOWN FOR ARTICLE}

Taylor \& Francis makes every effort to ensure the accuracy of all the information (the "Content") contained in the publications on our platform. However, Taylor \& Francis, our agents, and our licensors make no representations or warranties whatsoever as to the accuracy, completeness, or suitability for any purpose of the Content. Any opinions and views expressed in this publication are the opinions and views of the authors, and are not the views of or endorsed by Taylor \& Francis. The accuracy of the Content should not be relied upon and should be independently verified with primary sources of information. Taylor and Francis shall not be liable for any losses, actions, claims, proceedings, demands, costs, expenses, damages, and other liabilities whatsoever or howsoever caused arising directly or indirectly in connection with, in relation to or arising out of the use of the Content.

This article may be used for research, teaching, and private study purposes. Any substantial or systematic reproduction, redistribution, reselling, loan, sub-licensing, systematic supply, or distribution in any form to anyone is expressly forbidden. Terms \& Conditions of access and use can be found at http://www.tandfonline.com/page/termsand-conditions 


\title{
The Three Critical Flaws of Critical Geopolitics: Towards a Neo-Classical Geopolitics
}

\author{
TERRENCE W. HAVERLUK, KEVIN M. BEAUCHEMIN, \\ and BRANDON A. MUELLER \\ Academy Scholars Program, United States Air Force Academy, USAFA, CO, USA
}

\begin{abstract}
Critical geopolitics is the dominant school of geopolitics in contemporary geography. Critical geopolitics is a body of radical scholarship that emerged in the 1980 s that attempts to move beyond classic geopolitics. In order to resuscitate geopolitics, critical geopoliticians had to distance themselves from the imperialist, racist, and environmentally determinist geopolitics of the 1940s. In doing so, however, critical geopoliticians created a body of scholarship that omits important explanatory variables necessary to understand post-Cold War geopolitics. We argue that critical geopolitics unnecessarily limits the wider application of geopolitics because it is: 1) anti-geopolitics; 2) anti-cartographic; and 3) anti-environmental.
\end{abstract}

\section{INTRODUCTION}

Critical geopolitics is the dominant school of geopolitics in United States geography departments. ${ }^{1}$ Critical geopolitics is "a perspective within political geography and international relations that has developed since the early 1980s within international academia" that attempts to move beyond classical geopolitics by employing the three "beyonds": beyond political realism; beyond wise men; and beyond the absence of power. ${ }^{2} \mathrm{~A}$ reinterpretation of geopolitics was necessary because from the 1890s to the 1940s geopolitics was imperialist, racist, environmentally deterministic, and worked closely with imperial state governments to achieve geopolitical goals. After World War II, geopolitics was shunned by academic geographers. In order to

This article not subject to US copyright law.

Address correspondence to Terrence W. Haverluk, Department of Economics and Geosciences, 2354 Fairchild Hall, Suite 2345 Fairchild Hall, USAFA, CO 80840, USA. E-mail: terrence.haverluk@usafa.edu 
resuscitate geopolitics, academic geographers had to move beyond the sins of classical geopolitics, which are well documented. ${ }^{3}$ But, by re-introducing geopolitics as "critical," We argue geographers "threw out the baby with the bathwater."

In moving "beyond" classical geopolitics, critical geopolitics labelled itself "anti-geopolitics." Whereas classical geopolitics was the handmaiden of the imperialist state, "anti-geopolitics" actively works to alter international and domestic state power structures through "counter-hegemonic discourse(s)." Black argues that critical geopolitics can be better described as "radical" geopolitics. Radical geopolitics deliberately sets out to alter the categories and relationships established in classical geopolitics. In some cases it replaces the imperialist wishful thinking of classical geopolitics with "utopian wishful thinking" of the radical left; or by the "replacement of common sense by a particular jargon or discourse as well as of self-referential and self-reverential patterns of verification and endorsement within their own field ..." In short, "critical geopolitics is an aspect of a politicized debate, rather than the product of an academic culture as classically understood." ${ }^{4}$ We argue that both classical geopolitics and critical geopolitics are political movements that use geopolitics to advance their social agendas. Each school has an underlying political agenda that blinkers their world views.

Anti-geopolitics is only one sub-field of critical geopolitics, others include popular geopolitics, formal geopolitics, and feminist geopolitics. Popular geopolitics studies the process by which geopolitical ideas are "produced and reproduced through popular culture." Formal geopolitics studies the ways in which official foreign policy actors, think tanks, and academics mediate geopolitical issues so that certain ideas become policy prescriptions. These prescriptions can become hegemonic. Once they become hegemonic, they become axiomatic, such as the "Global War on Terror" (GWOT) and the statement from President George W. Bush that "you are either with us or with the terrorists." This axiom was then used to expand the powers of the surveillance state ${ }^{6}$. Feminist geopolitics refers to analyses and political interventions "that address the unequal and often violent relationships among people based on real or perceived differences." "As with radical geopolitics, these discourses attempt to alter, expose, or "intervene" to challenge established power structures at a scale "finer and coarser than the nation-state."

In lieu of these politicised geopolitics, we present a "neo-classical" geopolitics that relies on the enduring role of geography in global conflict and economic development.' Invoking geography as a cause of underdevelopment and conflict is part of a broader intellectual agenda that has emerged in the last fifteen years, mainly from non-geographers. ${ }^{10}$ Along with being "anti-geopolitics," we argue critical geopolitics is also "anti-cartographic" and "anti-environmental." The first two critiques are fairly straightforward and can be readily summarised, the environmental critique is more nuanced, however. Imbedded in our critiques is an argument for a neo-classical geopolitics. 
If geopolitics cannot move past "anti," or "radical," it will continue to be a marginalised sub-field in a marginal discipline. In fact, much of the scholarship on the influence of geography on economic development and global conflict is produced by non-geographers. We should re-claim what is rightfully ours.

\section{ANTI-GEOPOLITICS}

Classic geopolitik and its links to state power and imperialism meant that critical geopoliticians have defined their discourses as "anti" or "interventionist." Anti-geopolitics not only distances itself from state power structures, it actively seeks to alter state power structures. Although successful in altering the discourse in the geographic literature and becoming a consolidated academic "stream," they have not been successful at substantively altering contemporary hegemonic structures. As a result, critical geopoliticians are far from the corridors of power and therefore have little influence on decision makers. It is unlikely that government bureaucrats in the Department of Defense, Department of State, military war colleges, military academies, the US Congress, Washington "think tanks," or presidential cabinets read critical geopolitics. Instead they read political scientists, some of whom reside in academic departments that were created by the US government through generous grants established after World War II with links to the Department of State and Washington DC think tanks. No geographers were included in President Obama's foreign policy team, instead it is populated by economists, sociologists, retired military members, and political scientists. The same was true of the Bush and Clinton administrations - geographers are not included in the state power structure. (We suggest change from within is more effective than change from without.)

The dominant theories in international relations are realism, liberalism, and constructivism, with realism being the more widespread among US policymakers. Realists argue that states are self-interested, power-seeking, rational actors who attempt to maximise their security and survival at the expense of "others." Its basic premise is that "the strong do what they can and the weak suffer what they must."11 Dick Cheney's constant threats toward Iran align with the realist school. Critical geopoliticians are also antirealists, arguing that realism is the political science equivalent of classical geopolitics. ${ }^{12}$

Radical geopolitics turns realist competition on its head by turning it inward and directing the gaze toward the state itself. Anti-geopolitics is an intentionally isolated dissident voice in the wilderness. According to Routledge ${ }^{13}$ :

Anti-geopolitics can be conceived as an ambiguous political and cultural force within civil society - i.e. those institutions and organizations which 
are neither part of the processes of material production in the economy, nor part of state-funded or state controlled organizations (e.g. religious institutions, the media, voluntary organizations, educational institutions and trade unions - that articulates two interrelated forms of counterhegemonic struggle. First, it challenges the material (economic and military) geopolitical power of states and global institutions, and second, it challenges the representations imposed by political elites upon the world and its different peoples, that are deployed to serve their geopolitical interests.

You can't get more "anti" than that! The above definition would exclude even critical geopoliticians themselves - at least those employed by universities and colleges. Because of their intentional isolation, critical geopolitics has little influence in foreign policy or the military industrial establishment. There is some question as to whether political influence is an appropriate goal of academics, nevertheless, it is a key part of critical discourse(s). Instead of working from within, critical geopolitics relies on the "dissident intellectual" working outside the establishment to try to effect change. The exemplar of the dissident intellectual is the Zapatista rebel leader subcomandante Marcos. ${ }^{14}$ Marcos was a college professor who organised a group of Mayan farmers in Mexico to violently oppose the North American Free Trade Agreement (NAFTA) in an attempt to increase Maya political autonomy in 1994. (Critical geopoliticians are almost uniformly anti-globalisation and antineo-liberalism.) Since the Marcos-led liberation movement began in 1994, it has devolved into yet another critique of neo-liberalism and globalisation - and the states of Chiapas and Oaxaca - the Southern Mayan homeland, are still the two poorest states in terms of per capita GDP in Mexico. ${ }^{15}$ The Zapatistas are critical of all three major Mexican political parties and refuse to work within the state power structures, hence, like much of critical geopolitics, the Zapatista movement has become a marginalised, dissident critique of neo-liberalism, globalisation, and the traditional political process.

In fact, much of anti-geopolitics is a "critique." Consider Roberts, Secor, and Sparke's article on "Neoliberal Geopolitics." 16 Their main example of neo-liberal geopolitics is Thomas Barnett's paper on the "Pentagon's New Map." 17 They critique the map as simplistic, binary, unworkable, egoistic, hetero-patriarchical, and full of psychosexual language. They also critique the "Mackindersque" imperial legacy represented by Barnett's cartography the "Gods-eye view" that over-simplifies the world. Dalby ${ }^{18}$ argues much the same; Barnett "explicitly tries to render the world in a cartography of safety and danger" thereby creating a divided planet. Dalby argues Barnett's map is an example of "tabloid populism" that simplifies global conflict that also creates public support for US interventions in the "Gap." These critiques, while perhaps valid, are simply critiques; there is no alternative geopolitics provided. In fact, Dalby recognises this in his conclusion, "Hardt and Negri 
are frustratingly vague on what forms of resistance to war as the dominant social relation might take." 19

Ó Tuathail et al. have attempted to advance a sub-field of critical geopolitics by focusing on how geopolitics is (re)presented in popular culture, called popular geopolitics. But popular geopolitics is primarily a critique of how those in power use the media to propagandise and justify this or that military adventure. Because critical geopolitics is self-proclaimed antigeopolitics, it is anti-influential outside a small circle of academics and it facilitates the marginalisation of geography as an academic discipline.

\section{ANTI-CARTOGRAPHIC}

Critical geopolitics is also anti-map. Radical geopoliticians do not employ remote sensing, geographic information science, global positioning systems, computer cartography, or other geographic techniques in their analyses. From the publication of Ó Tuathail's seminal book on Critical Geopolitics in 1996 to Dalby's 2008 Geopolitics article on the "Continued Relevance of Critical Geopolitics" we have looked at fifteen of the more influential books and articles - over 1,500 pages - and found a total of eight maps, and most of these are simple locator maps or included only to critique them. ${ }^{20}$ The second edition of the Geopolitical Reader is 284 pages and includes only one map - Mackinder's 1904 map of the "World Island," but has thirteen cartoons. ${ }^{21}$ Mackinder's map is included only so that it can be critiqued.

This anti-map stance can be traced back to classic geopolitics and especially Mackinder's agenda to use maps to "geo-graph" the world, to "write territory" for the imperialist agenda of the British Empire. In mapping the empire the British created Ireland, created British East Africa and many other places by focusing the British "scientific imperial eye" on its territories. ${ }^{22}$ By elevating the visual, scientific agenda through maps, Mackinder's geopolitics became a practice of "visualizing and surveying global space with a view that writes." ${ }^{3}$ Since critical geopolitics has a radical, anti-imperial agenda, the use of maps could be misconstrued as condoning a Western imperialist agenda.

Maps are an important tool in geopolitics and essential when attempting to explain global conflict, but they are studiously avoided in critical geopolitics. Let's look again at Roberts, Secor, and Sparke's critique of Thomas Barnett's "Pentagon's New Map."

According to Barnett the areas within the lines in Figure 1 represent parts of the world that are "disconnected," i.e., they lack the rule of law, a robust judiciary, functioning institutions, a working infrastructure and high speed internet connections. It is here where the US is fighting terrorists, pirates, drug smugglers, gun runners, and human traffickers. These are also the places where the US military has deployed most often since 1990 (Figure 1, Appendix A). Barnett calls this part of the world the "Gap." 


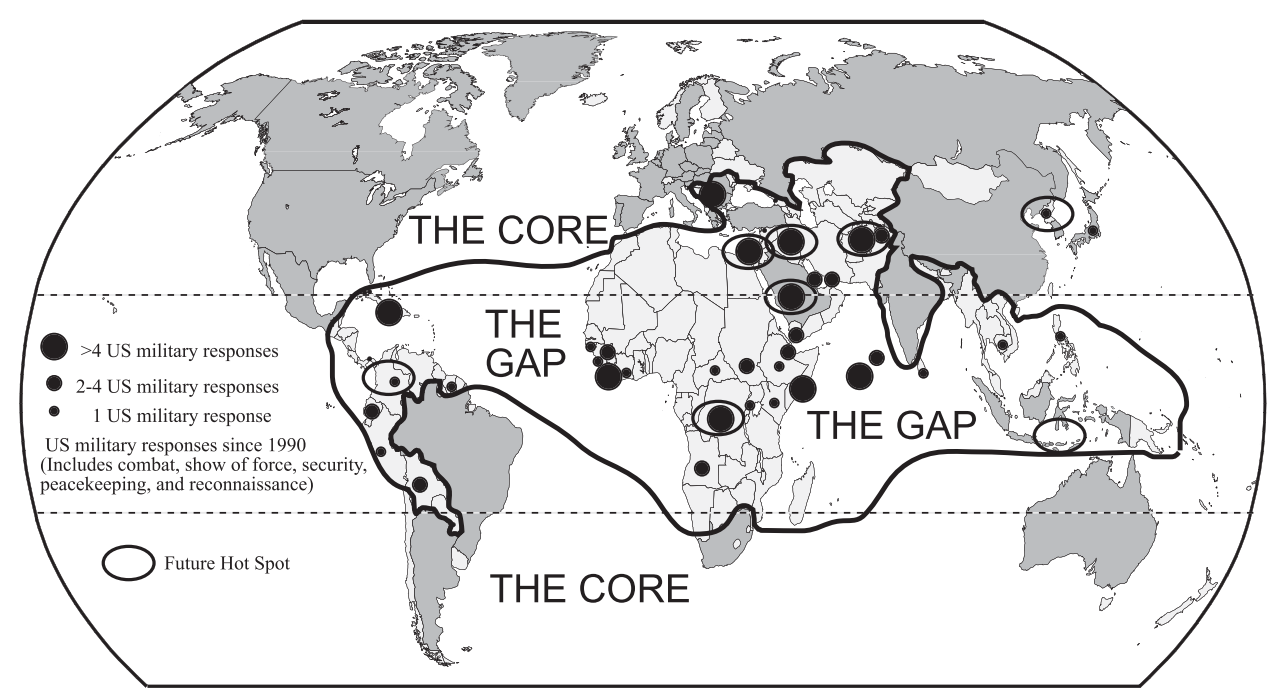

FIGURE 1 The Pentagon's New Map, Barnett's "Gap" and G-20 states shaded. Source: Barnett (2004).

The "Core" in Figure 1 consists of those states outside the "Gap." This core constitutes most of the Group of 20 states (G-20). Barnett, unknowingly, identified the G-20 as constituting the global "Core," and, in fact, the G-20 is the core of the global economy. The G-20 constitutes 90\% of global GDP, 85\% of global trade, and $75 \%$ of global population. ${ }^{24}$ Barnett argues that the disconnect in the Gap fosters terrorism and repressive regimes. His advice to the Pentagon is that by shrinking the Gap, the Core could increase their security and reduce terrorism. Barnett specifically states that neo-liberalism has the potential to shrink the gap - which is anti-anti-geopolitics. Roberts, Secor, and Sparke argue that Barnett's neo-liberal, pro-globalisation argument, like modernity and development before it (and let's not forget Marxism), is a totalising discourse that presents the false idea that free trade is the path to world peace and prosperity.

To Roberts, Secor, and Sparke, "The map is both that which is to be explained and the explanation itself, descriptive of the recent past and predictive of future action. For Barnett, the map reveals an indisputable pattern from which geopolitical knowledge can be read." 25 It is "binary" and Barnett seems intent to create the Gap as a continuous area. There is no "Gap in the Core and no Core in the Gap; no details that might disrupt his Mackinderesque bands of homogenized planetary difference." ${ }^{26}$ Again the few maps employed by critical geo-politicians are the ones they critique in the Geopolitical Reader it was Mackinder's map of 1904, and now it's Barnett's map of 2003. Political scientists and economists don't seem to have any problems analysing conflict at a global scale, i.e., "Mackinderesque," but 
in critical geopolitics any attempt to map the world at the global scale is usually dismissed as "Mackinderesque" and therefore imperialist, racist, sexist, and deterministic. ${ }^{27}$ According to critical geopolitics, after one hundred years, geographers are still getting their maps wrong.

Roberts, Secor, and Sparke go on to say that the "Gap thus represents a (f)rigid and torrid zone, both wretched and resistant." They continue by stating the audience for Barnett's map is just "one more incarnation of the masculine authority figure, the hetero-patriarchical savior ... (read Mackinder)." ${ }^{28}$ Even if their critique is correct, it is tautological because just as the map "is that which is to be explained and the explanation itself" the critique of the map is that which is to be critiqued and the critique itself. In their conclusion there is no alternative geopolitics provided, but simply a critique of how the map was purportedly used to persuade people in power to invade Iraq and advance a neo-liberal, Western imperial agenda.

Rather than simply critiquing the 2,000-year-old Greek latitudinal zonation model, critical geopolitics could include more nuanced environmental hypotheses such as those presented in Jeffrey Sach's European Mortality Index; Jared Diamond's founder crop hypothesis; Fareed Zakaria's explanation of the rise of Europe; or Jim Lee's eco-regional approach to global conflict. ${ }^{29}$ Yes, the Greek model was simplistic and (f)rigid, but there have been real advances in physical and economic geography over the last 2,000 years, which brings us to our third critic - radical geopolitics is anti-environmental

\section{ANTI-ENVIRONMENTAL}

The first two critiques of critical geopolitics are fairly straight-forward - they are self-described "anti" and they employ cartoons instead of maps in their analysis. Critical geopoliticians do, however, clearly discuss the environment. Critical geopolitics is therefore not anti-environmental per se. The Geopolitics Reader devotes several chapters to environmental geopolitics. ${ }^{30}$ The environment, however, is not presented as a causal factor in underdevelopment or global conflict. Instead, environmental problems are associated with "discourses of danger" as defined by the "North" and thought to be "little more than attempts to reassert Northern corporations' and political institutions' colonial domination of Southern societies, albeit now sometimes in the name of protecting the planet." ${ }^{31}$ In critical geopolitics, environmental degradation is a symptom of Northern exploitation of the South and another reason to protest globalisation and neo-liberalism.

Critical geopoliticians almost exclusively present environmental issues through anthropogenic problems such as climate change, ozone depletion, water pollution, and radioactive waste, and almost always caused by the exploitative global North. ${ }^{32}$ Because of the sins of classic geopolitik and 


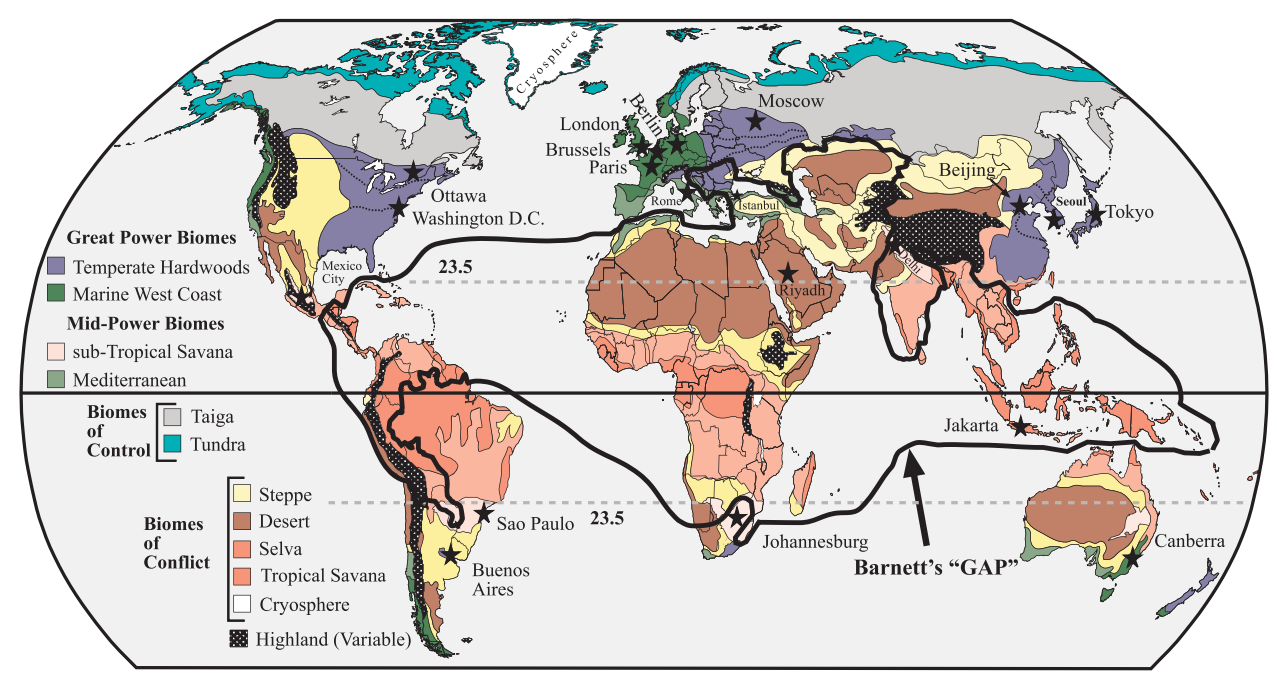

FIGURE 2 Global Biomes, the Pentagon's New Map, and the G-20.

Sources: Goode's World Atlas; Köppen, Küchler and Crowley; <http://www.g20.org/index. aspx>; Barnett (2004).

its links to environmental determinism, critical geopolitics steadfastly avoids linking the environment to development and global conflict. Yet, a geographical analysis using global biomes can help us understand the environmental underpinnings of global conflict, wealth creation, population density, and the distribution of power. States whose ecumene includes one of the four Biomes of Power dominate military power rankings - sixteen of twenty. ${ }^{33}$

Using Figure 2, we argue there is no such thing as a global "North" that exploits a global "South." The G-20 core countries are not divided north-south, but are dominated by "metropoles" 34 or "ecumenes" 35 in identifiable terrestrial biomes: two great power biomes; Marine West Coast and Temperate Hardwoods; and two mid-power biomes: Mediterranean and subTropical Savanna (Figure 2, Appendix A). Remember, the G-20 produces 90\% of global GDP and controls $85 \%$ of global trade - and eighteen G-20 states are located in one of the biomes of power. ${ }^{36}$

Figure 2 reveals that the ecumene of the G-20 are distributed as follows:

Temperate Hardwood Biomes:

a. The Washington DC-Boston corridor - Megalopolis (Köppen Dfa);

(You can extend this American ecumene west to Minneapolis, south to Dallas/Houston, and east to Atlanta.)

b. The Toronto-Ottawa-Montreal corridor (Köppen Dfb);

c. The Moscow-Novgorod-St. Petersburg triangle (Köppen Dfb);

d. The Beijing-Tianjin corridor (Köppen Dwb); 
e. The Tokyo-Osaka corridor (Köppen Cfa));

f. The Seoul metropolitan region (Köppen $\mathrm{Cfa}$ ).

Marine West Coast:

a. The London-Paris-Berlin-Brussels-Milan "Blue Banana" ${ }^{37}$ (capitals of the major EU countries and the EU, all Köppen $\mathrm{Cfb}$ );

b. The Sydney-Melbourne corridor (Köppen Cfb);

c. Eastern South Africa (Köppen Cfb, Cwb);

d. Buenos Aires (Köppen Cfa).

Countries in these two "Great Power Biomes" (including the EU), created 49 trillion of the world's 63 trillion dollars of Gross Domestic Product (GDP) in 2010. ${ }^{38}$

Seventy-seven percent of global GDP!

There are 181 countries on the IMF list and these ten political entities produced $77 \%$ of the world's wealth in 2010 . The rest of the world's 172 countries are simply outliers, but there are a few important outliers that need to be added to the list of power biomes.

Sub-Tropical Savanna:

a. The Indo-Gangetic plain with the capital in New Delhi (Köppen Cwa);

b. The Southern Brazilian corridor including Sao Paulo, Rio de Janeiro and Curitiba (Köppen Cwa, Cfa);

c. The Meseta Central in Mexico (including Mexico City, Köppen Cwa).

The better known, but less important mid-power biome, is the Mediterranean (Köppen Csb). Famous for its diet, coastal location, great views, tourism, and famous vineyards (Napa Valley, California; Maule Valley, Chile; Cape Town, South Africa; South Australia; and of course, the Mediterranean itself), it is the principle biome in only one G-20 country Turkey. The Mediterranean Biome is widespread, but is usually part of a country politically controlled by power nodes in one of the other Biomes of Power. For example, southern Portugal, southern Spain, southern France, southern Italy, southern California, western Australia, and western South Africa are lesser partners to power nodes in other biomes. Only Cyprus, Greece and Malta in the EU are primarily Mediterranean. Chile's population and power base is the Mediterranean biome, but it is not part of the G-20. Mediterranean countries are almost always high income because their amenities provide diversion to elites in the power biomes and because they have been conquered and settled by Europeans. Other Biomes of Power 
were also colonised and settled by Europeans in North America, South America, South Africa, Australia, and New Zealand.

These four "mid-Power" countries created 6 trillion of global GDP, or 10\% of global production in 2010. Together, territories controlled by metropoles in the Great and mid-Power Biomes produced 87\% of global GDP in 2010 (Appendix B).

We therefore disagree with the torturous, anti-geographical definition of a global "North" that includes Australia and New Zealand that exploits a global "South" that includes China and India. We replace the "North" with the Biomes of Power that includes previous "Southern" states such as Argentina, Australia, Brazil, China, India, Mexico, and South Africa. We argue that geography has direct causative impacts on population, per capita income, wealth creation, European mortality and power capabilities. If we overlay Barnett's "Gap" on a map of global biomes several hypotheses emerge (Figure 2).

First, Barnett's "Core" consists of the Biomes of Power. The stars in Figure 2 represent the metropoles/ecumenes of G-20 countries. Dalby makes a similar argument when he states, "... elites extend their control over productive resources (in a process called "resource capture") and displace peasants and subsistence farmers ("ecological marginalization")." 39 Dalby blames the global "North" for this phenomenon, but elites in the Biomes of Power, whether they be Chinese Han in Beijing, Indo-Aryans in Delhi, Russian Slavs in Moscow, or Portuguese speakers in Sao Paulo, are exploiting peripheral biomes, both in and outside of their sovereign states. These peripheral biomes include the Tropical Selva, Tropical Savanna, Steppe, Desert, Taiga, Tundra, and the Cryosphere - the Biomes of Conflict.

Elites located in the Biomes of Power all over the world "geo-graph"; it is not an exclusive activity of Western, white male elites. A small group of Han Chinese in Beijing are aggressively geo-graphing the South China Sea as we write. The new Chinese passport shows a map of China that "writes" greater China (Figure 3). The 9-dash map is an attempt to create order out of (dis)order in the South China Sea through Chinese cartography - backed up by the Chinese military presence in the area. ${ }^{40}$

The Han are not the only elites in the Biomes of Power who are geographing - the Indo-Aryans in New Delhi are writing Kashmir for internal consumption; the Russians are writing the territory of their "near abroad"; the Guatemalan military still produces maps with Belize as a territory of Guatemala; light-skinned, Spanish-descended elites on the Mexican Meseta Central are "resource capturing" from Mayans in the Jungle. All of these geo-graphings are eerily reminiscent of Mackinder's early twentieth-century agenda, yet none are "Western." 41

Second, when elites from the Biomes of Power exploit the people and resources of peripheral regions, conflict often ensues. Again, Dalby argues, "In some cases, this process (resource capture) may be connected to state failure and political violence, especially in those developing states in which 



FIGURE 3 China's "9-dash" map on the new Chinese passports (color figure available online). Source: <http://www.businessinsider.com/chinas-new-passport-maps-disputes-2012-11>.

insurgencies feed on grievances related to injustice and inequity." 42 Resource capture, ecological marginalisation, injustice and inequity have been the development model in the Americas for the last five hundred years. For example, Argentina, Bolivia, Brazil, Chile, Colombia, Mexico, and the US, are controlled by the descendants of European colonialists who violently seized the Biomes of Power for themselves. Colonial Europeans forced indigenous peoples into the biomes of marginality and conflict - the highlands of Bolivia, the jungles of Brazil, or the deserts of Mexico. In the United 
States, indigenous peoples were relocated to deserts, semi-arid grasslands, Rocky Mountain enclaves, the tundra, or on the margins of the northern boreal forests. North American temperate hardwoods were violently seized by European colonialists who then created the most powerful state in history - the United States of America. The Chinese, from temperate Beijing, exploit the resources of the Tibetan highlands, western deserts, and southern tropics, as well as extracting resources and exploiting the people in several African countries.

Rather than arguing that the cause of poverty is related to "Northern" corporate exploitation of the "South," we argue that it doesn't matter that Barnett is an apologist for neo-liberalism, or that he is hetero-patriarchical, what matters is that geography matters. We argue that both Barnett and his critics miss the point. Elites in "metropoles" control the Biomes of Power and exploit the people and resources in the Biomes of Conflict, even in their own countries. For example, elites located in Ottawa, Moscow, and Washington DC decide what happens in the Taiga, Tundra and the Cryosphere. Dissident intellectuals, Hollywood stars, and Greenpeace activists can rally to defend the rights of Inuits, but if the Canadian military wants to build bases in the far north, it will. ${ }^{43}$

Third, the Southern Hemisphere "Gap" line quite clearly reflects the "European Settler Mortality Index" (ESMI). The economists Acemoglu, Johnson, and Robinson ${ }^{44}$ argue that the ESMI is one of the most important variables in explaining global wealth distribution. Essentially, the ESMI states that those biomes similar to Europe allowed Europeans not only to conquer those lands, but to settle them as well. By settling these regions, Europeans also established the rule of law, private property rights, universal education and especially constraints on government expropriation that facilitated development. This is why the wealthiest countries in the southern hemisphere - Australia, Argentina, Brazil, Chile, New Zealand, and South Africa - were settled by Europeans, primarily because of their geographic similarity to Europe. Tropical places where Europeans died in great numbers because of diseases - 87\% of British soldiers died in Gambia in 1805 - were still colonised, ${ }^{45}$ but became resource colonies of Europe. Europeans did not settle these places and the rule of law and key institutions were never implemented, creating the "Gap."

Fourth, all the world's major shatterbelts are in the "Gap." There are several definitions of what constitutes a shatterbelt, but we define it as a group of usually small, weak states that have been fought over by great powers. They often occur in geologically complex regions at the intersection of plate boundaries such as the Caribbean, the Balkans, the Caucasus Mountains, the Middle East, and Southeast Asia. Notice that the Balkans, while part of the productive Temperate Hardwood and Mediterranean biomes, is not in the "Core" because it is a shatterbelt that has been fought over by the Romans, Greeks, Persians, Hungarians, Austrians, Russians, Turks, and most recently 
Serbian and NATO forces. The same is true of the Caribbean where the collision of five tectonic plates has created a disconnected, mountainous, island-filled shatterbelt with over twenty countries speaking at least six languages. Now let us make this perfectly pellucid - tectonic plates do not cause shatterbelts - but they do provide some of the conditions that allow them to exist. Mountain peoples are not inherently violent as suggested in classic geopolitik, but they do provide an excellent refuge when elites in metropoles attempt ethnic cleansing. The Chechens and Kurds are quite thankful of this fact.

Finally, even if Barnett's map is hetero-patriarchical, that critique misses the point. Barnett's map is a surrogate for environmental probabilism. The "Gap" consists of those parts of the world that are difficult to manage jungles, deserts, high mountains, vast boreal forests, treeless tundra, disjointed island archipelagos, and shatterbelts. There are a few scholars who address the concept of environmental probabilism: Harold and Margaret Sprout in 1957, Raymond Aron in 1966, and Fernand Braudel in $1987 .{ }^{46}$ The Sprouts argued for the existence of "common sense probabilism," which is a behavioural model whose function is to "enable the analyst to arrange a set of possible choices on a sort of continuum of estimated degrees of probability." 47 When used in a biome-centric analysis of the "Gap" and the "Core" it is with a high degree of probability that we predict Chad, a landlocked desert state three times the size of California, but with a population one-fourth the size, will be a low power state susceptible to outside interference and political instability. We can similarly predict the same situation for several selva, highland, steppe, island, and shatterbelt states. There are several geographic factors why some states are perpetually weak and manipulated by stronger states - their location, climate, topography, and biome are as much a cause of underdevelopment as lack of education, debt burden, poor institutional infrastructure, corruption, income disparity, and neo-liberal economic exploitation by the "North."

Environmental probabilism is not part of the vocabulary of critical geopolitics, instead the environment is seen almost exclusively as an anthropogenic problem - desertification, climate change, radioactive fallout, ozone depletion, conflict diamonds, bioterrorism, emerging diseases, and pollution. ${ }^{48}$ The environment can, however, be a causal factor in geopolitics. Consider the following:

- *The 2004 Indonesian tsunami led to a peace accord between the Achenese and the Javanese ending a forty-year-long civil war. ${ }^{49}$

- ${ }^{*}$ The melting cryosphere, especially in the Arctic, has opened up the potential exploitation of rich fields of gas, oil, fisheries, and strategic transportation routes. Russia, Canada, Denmark, Norway and the US all have overlapping claims - based on underwater geology - and are in the process of militarising the far north. This competition is called cryopolitics. ${ }^{50}$ 
- *Long-standing geographic differences between Sudan and Southern Sudan created enduring ethno-religious differences that led to fifty years of civil war that has not been resolved by creating an independent Republic of Southern Sudan in 2011. The fact that the situation in the Sudans is still in flux is moot; the north-south divide is real and long-standing, exacerbated by British colonial policies due to geographic differences, especially diseases in the Southern Sudan. ${ }^{51}$

- *Hurricane Katrina destroyed off-shore oil rigs, increasing the price of oil, and set off riots in Indonesia. ${ }^{52}$

- *The La Niña event of 2010-2011 caused a prolonged drought in the Horn of Africa severely limiting crop production that caused a massive die-off of livestock leading to a refugee crisis. Mass migration has led to conflict between Somalis, Kenyans, Ethiopians, and the Al Shabab terrorist group. ${ }^{53}$

- Environmental constraints such as tropical disease burdens, mountainous terrain, and poor transportation infrastructure are thought to reduce economic growth by as much as $1.5 \%$ annually. ${ }^{54}$

Obviously, in each example above, there are multiple factors involved, but geography was a necessary, and in some cases not sufficient, variable. We would argue, however, that omitting these natural and "probabilistic" environmental effects means geographers are not using our entire tool kit.

\section{TOWARDS A NEO-CLASSICAL, HOLISTIC GEOPOLITICS}

Classic geopolitik of the late nineteenth and early twentieth century relied heavily on environmental determinism, racism, and propaganda, but these writers also discovered many geographic insights currently used by geostrategists in China, Russia, and Latin America, and by many non-geographers in the US. ${ }^{55}$ Yet, in their never-ending quest to move "beyond," critical geopoliticians have consistently avoided geography as a causal factor in underdevelopment and conflict.

Many writers, mostly non-geographers, have argued that geography is an important causal factor in economic development and power capabilities. We use not only geography, but other social factors to create a global risk assessment $^{56}$ (Figure 4, Appendix A).

Some states, because of their history and geography are at higher risk; others for the same reason are at lower risk. Because of its location, New Zealand is probably the most secure state on the planet, whereas Afghanistan is one of the least secure. ${ }^{57}$ Fragile shatterbelt states located in Mackinder's "rimland" of the World Island are more at risk, followed by several African states. The Holistic Global Risk index was created the same year Barnett published his Core-Gap hypothesis, but the author had no knowledge of his article, yet came to similar conclusions. 


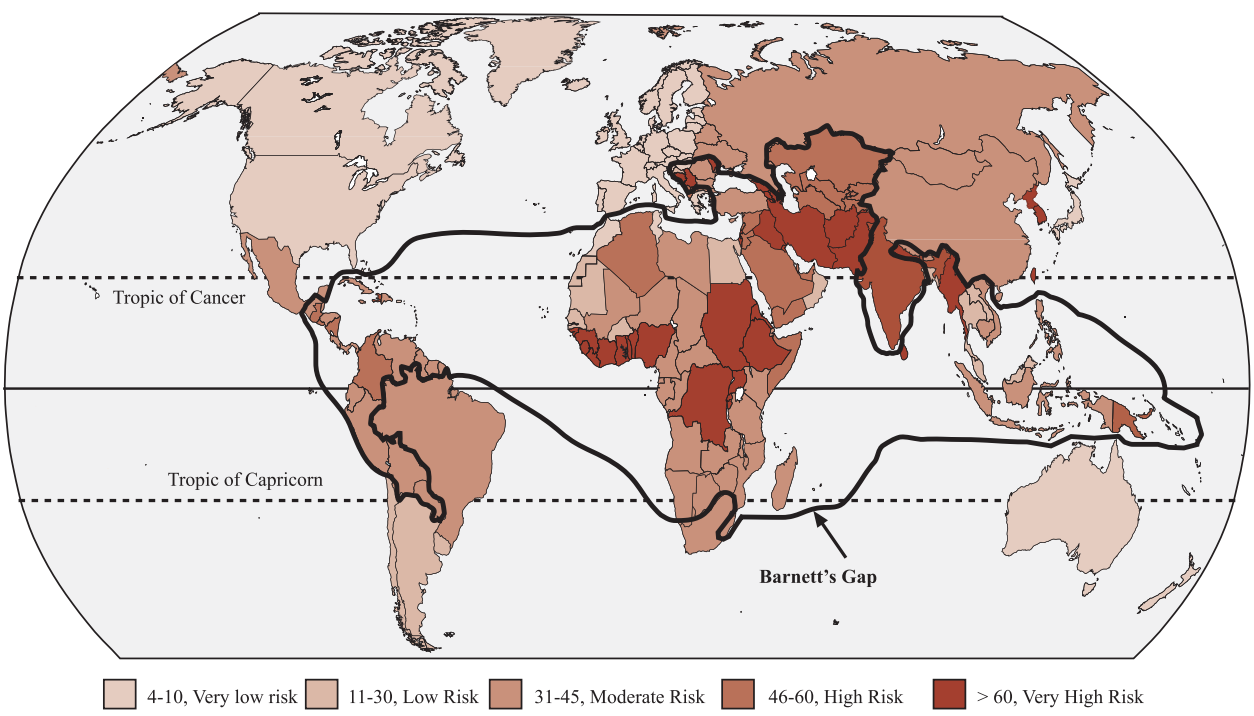

FIGURE 4 Holistic Global Risk Index (Haverluk 2007) and Barnett's Gap (color figure available online).

Sources: Barnett (2004); Appendix A.

\section{CONCLUSION}

Critical geopolitics is an important contribution to the geographic literature and an important sub-set of political geography, but by being "anti" - anti-geopolitical, anti-cartographical, and anti-environmental - critical geopoliticians have muted their potential influence both inside and outside of geography. "Anti" can take a discipline only so far. "Critical" geopolitics is important as part of the larger struggle to decolonise our inherited "geopolitik," but as a result it has become a politicised debate rather than an academic discipline classically understood. ${ }^{58}$ For geopolitics to advance, and for geography to have more influence, other aspects of the field need to be incorporated into our geopolitical toolkit. We argue for a more holistic, neo-classical geopolitics.

\section{NOTES}

1. A keyword search of "geopolitics" from the 2012 AAG conference website reveals thirty presentations on geopolitics from scholars at United States universities and colleges. Of those thirty, nine use the term "critical geopolitics" in their abstract or "key words" section. Five include the term "feminist geopolitics," three include "popular geopolitics," one includes "critical feminist geopolitics" and another uses the terms "social justice" and "geopolitics." In total, nineteen of the thirty presentations should be considered part of the umbrella of terms that constitutes "radical geopolitics."

2. G. Ó Tuathail, S. Dalby, and P. Routledge, The Geopolitics Reader (New York: Routledge 2006) pp. 5-12. The three "beyonds" are: 1) Political realism, which was the dominant discourse of 
international relations and is concerned with the struggle for power between unitary, rational actors called "states." Since the end of the Cold War, the assumptions and conclusions of realism have been widely challenged. 2) Wise men, which is the popular notion that geopolitics is an elite activity practised by white men at the centre of state power. The "wise man" is no longer dominant in geopolitics, its decline can be traced from the 1970s, to the early 2000s culminating with Condoleeza Rice and Hilary Clinton. And 3) the "absence of power" argument, which is the notion that classical geopolitics is explicitly concerned with power "between" states, but ignores the structure of power "within" states. Most contemporary writing on geopolitics acknowledges the structure of power within states as a potential constraint on power capabilities and geostrategy. All three "beyonds" are no longer dominant discourses in geopolitics, having died mostly a natural death. For example, C. Gray argues that geopolitical theory is "socially constructed, as critical theorists remind us, but so what? In the social sciences, what else could such a theory be"? (p. 168). The penchant for critical theorists to remind us of the "social construction of geopolitical theories" does not obviate the fact that many of these theories, past and present, explain only a partial slice of reality.

3. J. Black, Geopolitics (London: The Social Affairs Unit 2009) pp. 107-116.

4. Ibid., p. 202.

5. J. Dittmer, Popular Culture, Geopolitics, and Identity (Lanham, MD: Rowan and Littlefield 2010).

6. Address to a Joint Session of Congress and the American People, 20 Sep. 2001, available at $<$ http://georgewbush-whitehouse.archives.gov/news/releases/2001/09/20010920-8.html>.

7. J. Hyndman, 'Towards a Feminist Geopolitics', The Canadian Geographer 45/2 (June 2008) pp. 210-222.

8. Ibid.

9. T. W. Haverluk, 'The Biomes of Power and Conflict', Focus on Geography 52/4 (2010) pp. 66-69.

10. C. Ballinger, 'Why Geographic Factors are Necessary in Development Studies', Munich Personal RePEc Archive, available at <http://mpra.ub.uni-muenchen.de/29750>, MPRA Paper No. 29750 (22 March 2011); Black (note 3) pp. 198-202; R. Kaplan, 'The Revenge of Geography', Foreign Policy (May/June 2009); S. Cohen, Geopolitics: The Geography of International Relations (Rowan and Littlefield 2009); J. Grygiel, Great Powers and Geopolitical Change (Baltimore: Johns Hopkins University Press 2006) pp. 24-37; J. Sachs, 'Institutions Don't Rule: Direct Effects of Geography on Per Capita Income', National Bureau of Economic Research, Working Paper 9490 (Feb. 2003) p. 2; F. Zakaria, The Future of Freedom: Illiberal Democracy at Home and Abroad (New York: Norton 2003) pp. 30-45; D. Acemoglu, S. Johnson, and J. Robinson, 'The Colonial Origins of Comparative Development: An Empirical Investigation', NBER Working Paper 7771 (June 2000), available at $<$ http://www.nber.org/papers/w7771 >; J. Diamond, Guns, Germs, and Steel: The Fate of Human Societies (New York: W.W. Norton 1999) pp. 176-196; C. Gray and Geoffry Sloan, Geopolitics and Geostrategy (London: Frank Cass 1999) pp. 161-176; A. Chauprade and F. Thual, Dictionnaire de Géopolitique (Paris: Ellipse 1999) pp. 451-486; P. Krugman, 'The Role of Geography in Development', Annual World Bank Conference on Development Economics (Washington, DC: April 1998); P. Claval, Géopolitique et Géostrategie: Le Pensée, l'Espace et le Territoire au XX Siecle (Paris: Nathan Press 1996) pp. 67-84. Although not yet considered a "school" there is a large and growing literature among foreign geographers and American social scientists who argue geography is a causal factor in underdevelopment and global conflict. The above list includes historians, political scientists, economists, journalists, and one American geographer, Jared Diamond.

11. H. Morgenthau, Politics among Nations: The Struggle for Power and Peace (New York: McGraw Hill 1948) pp. 3-24.

12. Ó Tuathail et al. (note 2) pp. 6-12.

13. Ibid., p. 233.

14. Ibid., p. 263. Since the dominant school of geopolitics in the US is critical geopolitics, this article provides a dissident voice in the wilderness.

15. 'Chiapas', Instituto Internacional de Estadística y Geografía, 2010, available at <http://www3. inegi.org. $\mathrm{mx} /$ sistemas/mexicocifras/>.

16. S. Roberts, A. Secor, and Matthew Sparke, 'Neoliberal Geopolitics', Antipode 35 (2003) pp. 886-897.

17. T. Barnett, The Pentagon's New Map: War and Peace in the $21^{\text {st }}$ Century (New York: G. P. Putnam 2004) pp. 3-14. 
18. S. Dalby, 'The Pentagon's New Imperial Cartography: Tabloid Realism and the War on Terror', in D. Gregory and Allan Pred (eds.), Violent Geographies: Fear, Terror, and Political Violence (New York: Routledge 2007) pp. 295-308.

19. Ibid.

20. G. Ó Tuathail, Critical Geopolitics: The Politics of Writing Global Space (Minneapolis: University of Minnesota Press 1996); P. Le Billon, 'The Political Ecology of War: Natural Resources and Armed Conflicts', Political Geography (Cambridge: Elsevier Ltd. 2001) pp. 561-584; S. Dalby, 'Security and Ecology in the Age of Globalization', in Woodrow Wilson International Center for Scholars (ed.), Environmental Change and Security Project Report 8 (Summer 2002) pp. 95-108; Roberts et al. (note 16) pp. 886-897; P. Routledge, 'Anti-Geopolitics', in A Companion to Political Geography (Oxford: Blackwell 2003); J. Agnew, K. Mitchell, and G. Toal (eds.), A Companion to Political Geography (New York: Wiley 2003) ch. 16; J. Dittmer, 'Captain America's Empire: Reflections on Identity, Popular Culture, and Post 9/11 Geopolitics', Annals of the Association of American Geographers 95/3 (2005) pp. 626-643; G. Ó Tuathail, The Geopolitics Reader (New York: Taylor and Francis Group 2006); D. Gregory and A. Pred (eds.), Violent Geographies: Fear, Terrorism, and Political Violence (New York: Taylor and Francis Group 2007); S. Dalby, 'Imperialism, Domination, Culture: The Continued Relevance of Critical Geopolitics', Geopolitics (New York: Taylor and Francis Group 2008) pp. 413-436; Hyndman (note 7) pp. 210-222; J. Dittmer and K. Dodds, 'Popular Geopolitics, Past and Future: Fandom, Identities, and Audiences', Geopolitics 13/3 (2008) pp. 437-457; G. Kearns, Geopolitics and Empire (New York: Oxford University Press 2009); I. Emre, 'The US Grand Strategy and the Eurasian Heartland in the Twenty-First Century', Geopolitics 14/1 (2009) pp. 26-46; S. Dalby, 'Geopolitics, the Revolution in Military Affairs and the Bush Doctrine', International Politics 46/2/3 (2009) pp. 234-252; N. Megoran, 'Neoclassical Geopolitics', Political Geography 29 (2010) pp. 187-189. These fifteen works have a total of eight maps, by contrast, the International Relations text used by our political science department has three hundred pages and has fifteen colour maps on a global and regional scale, more than in almost 1,500 pages of critical geographers.

21. Ó Tuathail, Geopolitics Reader (note 20) pp. 1-38.

22. Ó Tuathail, Critical Geopolitics (note 20) pp. 24-55

23. Ibid.

24. The G-20 consists of Argentina, Australia, Brazil, Belgium (seat of the EU) Canada, China, France, Germany, India, Indonesia, Italy, Japan, Mexico, Russia, Saudi Arabia, South Africa, South Korea, Turkey, the United Kingdom, and the United States (<http://www.g20.org/ $>$ ). Based on this data it seems clear that the North/South, Core/Periphery conceptualisation no longer fits the facts. Does anyone believe that the US and the UK (the Global North) are exploiting Brazil or China (the Global South)?

25. Roberts et al. (note 16) p. 890.

26. Ibid., p. 892.

27. Ó Tuathail, 'Putting Mackinder in His Place: Material Transformations and Myth', Political Geography 11/1 (1993) pp. 100-118.

28. Roberts et al. (note 16) p. 892.

29. F. Zakaria, The Future of Freedom: Illiberal Democracy at Home and Abroad (New York: Norton 2003) pp. 30-59.

30. Ó Tuathail, Critical Geopolitics (note 20) pp. 177-185.

31. Ibid.

32. Dalby, 'Security and Ecology' (note 20) pp. 95-108.

33. The Biomes of Power - Marine West Coast, Temperate Hardwood, Mediterranean, and subTropical Savanna include the ecumenes/metropoles of sixteen of the top twenty militaries, in order: USA, Russia, China, India, UK, Turkey, South Korea, France, Japan, Israel, Brazil, Iran, Germany, Taiwan, Pakistan, Egypt, Italy, Indonesia, Thailand and Ukraine. (Italicised states are not in a Biome of Power.) Source: <http://www.globalfirepower.com/>.

34. G. Kearns, 'Bare Life, Political Violence, and the Territorial Structure of Britain and Ireland', in D. Gregory and A. Pred (eds.), Violent Geographies: Fear, Terror and Political Violence (New York: Taylor and Francis Group 2007) pp. 7-36.

35. S. Cohen, Geopolitics: The Geography of International Relations, 2nd ed. (Lanham, MD: Rowman and Littlefield 2009).

36. There are two G-20 states not in a biome of power: Saudi Arabia because of its vast oil deposits; and Indonesia with its large population astride the world's most important strategic choke point - the Straits of Malacca. 
37. R. Brunet, 'Ligues de Force de l'Espace Europeén', Mappemonde 66/2 (2002).

38. International Monetary Fund, World Economic Outlook Database, Nominal Gross GDP (April 2011), available at <http://en.wikipedia.org/list_of_countries_by_GDP_(nominal)\#cite_note_1 > .

39. Dalby, 'Security and Ecology' (note 20) pp. 95-108.

40. A. Taylor, 'China's New Passport Contains a Subtle Yet Undeniable Insult to Territorial Rivals', Business Insider, 23 Nov. 2012, available at <http://www.businessinsider.com/chinas-new-passportmaps-disputes-2012-11>.

41. Author's field notes.

42. Dalby, 'Security and Ecology' (note 20) p. 96.

43. 'Harper Announces Northern Deep-sea Port Training Site', Canadian Broadcasting Corporation, 11 Aug. 2007, available at <http://www.cbc.ca/news/Canada/story/2007/08/10/port-north.html> .

44. Acemoglu et al. (note 10) pp. 1369-1401

45. Ibid., p. 1375.

46. H. Sprout and M. Sprout, 'Environmental Factors in the Study of International Politics', Journal of Conflict Resolution 1/4 (Dec. 1957) pp. 309-328; R. Aron, Peace and War: A Theory of International Relations (Garden City: Doubleday 1966) p. 321; F. Braudel, The Mediterranean: And the Mediterranean World in the Age of Philip II, (Harper and Row, New York 1973).

47. Sprout and Sprout (note 46) pp. 309-328.

48. Ibid., p. 316.

49. Ó Tuathail et al. (note 2) 179.

50. T. W. Haverluk, 'The Age of Cryopolitics,' Focus on Geography 50/3 (2007), and T. W. Haverluk, Geopolitics from the Ground Up (New York: Wiley 2007) (2nd ed.).

51. Ibid.

52. Ibid.

53. Ibid.

54. United Nations Office for the Coordination of Humanitarian Affairs, Eastern African Drought Humanitarian Report \#4, July 2011, available at <http://reliefweb.int/node/426060>.

55. J. Sachs, Tropical Underdevelopment, prepared for Economic History Association Annual Meeting, CID Working Paper No. 57, Dec. 2000, available at < http://www.cid.harvard.edu/cidwp/057. htm $>$.

56. Risk includes, but is not limited to, inter- and intra-state war, insurgencies, terrorism, genocide, organised crime, illicit drugs, human trafficking, natural disasters, disease epidemics, drought, desertification and climate change. United Nations Development Programme, Reducing Disaster Risk: A Challenge for Development (New York: UN Bureau of Crisis and Recovery 2000); <http:// www.freedomhouse.org/sites/default/files/FIW\%202012\%20Booklet_0.pdf > ; <http://www.transparency. org/country\#SSD_DataResearch_SurveysIndices>; <https://www.cia.gov/index.html>; <http://heritage. org/research/features/index/indexfreedom.cfm>; <http://hdr.undp.org/en/reports/global/hdr2011/> .

57. Afghanistan, sandwiched in between Persia, South Asia, and Turkestan has been invaded multiple times through the Khyber Pass. The most recent was by the USSR in 1979, Al Qaeda in the 1990s, and the US in 2001. In fact, Afghanistan's current boundaries are the result of the "Great Game" between the Soviet Union and the British Empire. By contrast, New Zealand was not even settled until the 1200s and has been invaded only twice.

58. Black (note 3) pp. 107-116; Kaplan (note 10). Kaplan cites Alfred Mahan's thesis that the Indian Ocean will be a key geostrategic region in the twenty-first century; Spykman's prediction on the rise of China and the role of the Indian Ocean and the Pacific in checking Russian influence; Braudel's book on the importance of geography in global conflict; and, yes, even Mackinder for predicting both World Wars, among other things. 


\section{APPENDIX A}

Holistic global risk indices.

Geographic factors:

Is the country ecumene in one of the power biomes:

Marine West Coast, Temperate Hardwood, Mediterranean,

or sub-Tropical Savanna?

Partially?

5 points

3 points

Entirely excluded from a power biome

0 points

Does the state have deep water ports in the North Atlantic

North Pacific, or the Indian Ocean?

5 points

Does the state have deep water ports in the South Atlantic

or the South Pacific?

Is the state landlocked and/or lacking ports?

3 points

0 points

Is the country larger than $3,000,000$ sq. kilometres?

5 points

Is the country between 200,000 and 2,999,999 sq. Kilometres?

3 points

Is the country less than 200,000 sq. kilometres?

0 points

Is the country in the Köppen "C" or "Dwa" climate zone?

Is the country in any other Köppen "D" climate zone?

5 points

Is the country in the "A," "B," "E" Köppen climate zones?

3 points

0 points

Is the percentage of arable land greater than $15 \%$ ?

5 points

Is the percentage of arable land between 10 and 14.99\%

Is the percentage of arable land less than $10 \%$

3 points

0 points

Maximum Geographic Points

25

Demographic Factors

Does the state population have a life expectancy greater than 70 years?

Does the state population have a life expectancy between 50 and 69 years?

5 points

3 points

Does the state population have a life expectancy less than 50 years?

0 points

Is the Male-Female ratio of the population higher for females?

Is the Male-Female ratio of the population nearly equal?

5 points

Is the Male-Female ration of the population higher for males?

3 points

0 points

Is the state's infant mortality rate less than 10 per 1,000 ?

5 points

Is the state's infant mortality rate between 11 and 20 per 1,000 ?

3 points

Is the state's infant mortality rate greater than 21 per 1,000

0 points

Is the state's literacy rate greater than 95 percent?

5 points

Is the state's literacy rate between 80 and 94 percent?

3 points

Is the state's literacy rate less than 80 percent?

0 points

Is the state's population educated 12 years or more?

Is the state's population educated between 10 and 12 years?

5 points

Is the state's population educated less than 10 years?

3 points

0 points

Maximum Demographic points

Economic Factors

Is the state's per capita GDP greater than $\$ 30,000$ ?

Is the state's per capita GDP between $\$ 10,000$ and $\$ 29,999$ ?

5 points

Is the state's per capita GDP less than $\$ 10,000$ ?

3 points

0 points 


\section{APPENDIX A (Continued)}

Is the percentage of the population engaged in agriculture $<5 \%$

Is the percentage of the population engaged in agriculture between 6 and 25\%

5 points

Is the percentage of the population engaged in agriculture $>25 \%$

3 points

0 points

Is the unemployment rate less than $10 \%$ ?

Is the unemployment rate between 10 and $25 \%$ ?

5 points

Is the unemployment rate greater than $25 \%$

3 points

0 points

Maximum Economic Factors

15

Political Factors

Is the country a democracy?

Is the country somewhat democratic?

5 points

3 points

Is the country un-democratic?

0 points

Are women allowed to vote?

5 points

Are women not allowed to vote?

0 points

Does the country have a free press?

Does the country have a partially free press?

5 points

Is there no free press in the country?

3 points

0 points

Is the state monogamous?

5 points

Is the state partly monogamous?

Is the state polygynous?

3 points

0 points

Maximum political points

20

Technological and military factors

Does the state have nuclear weapons capability? 5 points

No nuclear weapons capability?

0 points

Does the state have a space/satellite programme?

5 points

No space/satellite programme

0 points

Does the state manufacture its own weapons?

5 points

The state does not manufacture its own weapons?

0 points

Maximum technical/military factors

15 points

Total points possible

100 


\section{APPENDIX B}

Cities greater than 5 million, their biome and Köppen climate classification, from greater to smaller populations.

\begin{tabular}{|c|c|c|}
\hline City & biome & climate \\
\hline 1) Tokyo & Temperate Hardwood & $\mathrm{Cfa}$ \\
\hline 2) Seoul & Temperate Hardwood & $\mathrm{Cfa}$ \\
\hline 3) Mexico City & sub-Tropical Savanna & Cwb \\
\hline 4) New York City & Temperate Hardwood & $\mathrm{Cfa}$ \\
\hline 5) Mumbai & Tropical Savanna & $\mathrm{Aw}$ \\
\hline 6) Jakarta & Tropical Selva & Af \\
\hline 7) Sao Paulo & sub-Tropical Savanna & Cwb \\
\hline 8) New Delhi & sub-Tropical Savanna & Cwb \\
\hline 9) Osaka & Temperate Hardwood & $\mathrm{Cfa}$ \\
\hline 10) Shanghai & Temperate Hardwood & $\mathrm{Cfa}$ \\
\hline 11) Manila & Tropical Selva & Af \\
\hline 12) Hong Kong & sub-Tropical Savanna & Cwa \\
\hline 13) Los Angeles & Mediterranean & Csa \\
\hline 14) Kolkata & sub-Tropical Savanna & AW \\
\hline 15) Moscow & Temperate Hardwood & Dfa \\
\hline 16) Cairo & Desert & BWh \\
\hline 17) Kolkata & Tropical Savanna & $\mathrm{Aw}$ \\
\hline 18) Buenos Aires & Temperate Hardwood & $\mathrm{Cfa}$ \\
\hline 19) London & Marine West Coast & $\mathrm{Cfb}$ \\
\hline 20) Beijing & Temperate Hardwood & Dwa \\
\hline 21) Karachi & Desert & BWh \\
\hline 22) Dhaka & Tropical Savanna & $\mathrm{Aw}$ \\
\hline 23) Rio de Janeiro & sub-Tropical Savanna & $\mathrm{Aw}$ \\
\hline 24) Tianjin & Temperate Hardwood & Dwa \\
\hline 25) Paris & Marine West Coast & $\mathrm{Cfb}$ \\
\hline 26) Istanbul & Mediterranean & $\mathrm{Cfa}$ \\
\hline 27) Lima & Temperate Desert & $\mathrm{B}$ \\
\hline 28) Tehran & Mediterranean & $\mathrm{Cfa}$ \\
\hline 29) Bangkok & Tropical Savanna & $\mathrm{Am}$ \\
\hline 30) Chicago & Temperate Hardwood & Dfa \\
\hline 31) Bogotá & sub-Tropical Savanna & Cwb \\
\hline 32) Hyderabad & hybrid & Aw/Bsk \\
\hline 33) Chennai & Tropical Savanna & $\mathrm{AW}$ \\
\hline 34) Essen & Temperate Hardwood & $\mathrm{Cfb}$ \\
\hline 35) Ho Chi Minh City & Tropical Savanna & $\mathrm{Am}$ \\
\hline 36) Hangzhou & sub-Tropical Savanna & $\mathrm{Cfa}$ \\
\hline 37) Lahore & sub-Tropical Savanna & Bsh \\
\hline 38) Shenyang & Temperate Hardwood & Dwa \\
\hline 39) Changchun & Temperate Hardwood & Dwa \\
\hline 40) Bangalore & Tropical Savanna & $\mathrm{Aw}$ \\
\hline 41) Harbin & Temperate Hardwood & Dwa \\
\hline 42) Chengdu & sub-Tropical Savanna & Cwa \\
\hline 43) Santiago & Mediterranean & Csb \\
\hline 44) Guangzhou & sub-Tropical Savanna & $\mathrm{Cfa}$ \\
\hline 45) St. Petersburg & Temperate Hardwood & Dwa \\
\hline
\end{tabular}

Source: <http://www.worldatlas.com/citypops.htm> 31 of 45 cities over five million are in one of the four Biomes of Power. 